\title{
Reactive oxygen species generated by cold atmospheric plasmas in aqueous solution: successful electrochemical monitoring in situ under a high voltage system
}

Fanny Girard-Sahun ${ }^{\mathrm{a}, \mathrm{b}}$, Vasilica Badets ${ }^{\mathrm{b}}$, Pauline Lefrançois ${ }^{\mathrm{b}}$, Neso Sojic ${ }^{\mathrm{b}}$, Franck Clement*a and Stephane Arbault*b

a UPPA, IPREM, CNRS UMR 5254, 2 avenue Président Angot, 64000 Pau, France

b Univ. Bordeaux, ISM, CNRS UMR 5255, INP Bordeaux, 33400 Talence, France

\section{Corresponding Authors:}

Dr Stéphane Arbault, email : stephane.arbault@u-bordeaux.fr Tel.: +33540008939 ;

Dr Franck Clément, email: franck.clement@univ-pau.fr Tel.: +33559 (407657) / (574190)

Supporting informations include the protocol for ultramicroelectrode fabrication (corresponding references at the end) as well as optical and SEM images of a modified UME (Figure S1). Then, a calibration by cyclic voltammetry in hydrogen peroxide + nitrite solutions of the UME used for measurements in Figure $4 \mathrm{~b}$ is described in Figure S2. 
UME fabrication. Modified UMEs were designed for these experiments: a thin Pt wire $(25 \mu \mathrm{m}$ diameter; $99 \%$ purity, Goodfellow) was sealed in a glass capillary for a final diameter close to $1 \mathrm{~mm}$ (Figure 1B). Each UME was polished with coarse- and fine-grade polishing papers before use and further modification. As already described ${ }^{1}$, the sensitivity of the working microelectrodes was enhanced by doing a potentiostatic electro-deposition of black platinum performed by reduction of hydrogen hexachloroplatinate $(115 \mathrm{mM} \text {, diluted in } 10 \mathrm{mM} \text { PBS, pH } 7.4 \text { with } 0.76 \mathrm{mM} \text { of lead acetate })^{2}$ at a potential of $-60 \mathrm{mV}$ vs $\mathrm{Ag} / \mathrm{AgCl} / \mathrm{NaCl} 3 \mathrm{M}$. The electrodeposition was stopped when the total reduction charge reached $0,07 \mu \mathrm{C} . \mu \mathrm{m}^{-2} 3$ (see Figure $\mathrm{S} 1$ ).

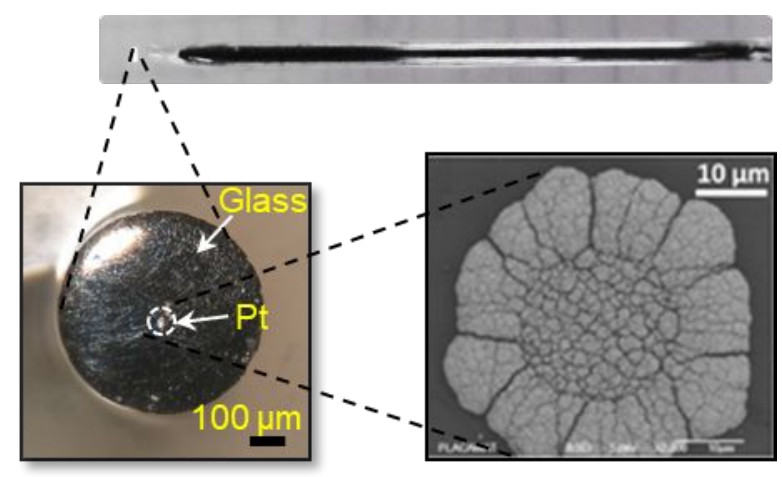

Figure S1. Multiscale view based on optical (top and down left) and SEM (down right) imaging of a platinized platinum ultramicroelectrode ( $\mathrm{Pt}$ wire $\varnothing 25 \mu \mathrm{m}$, total external diameter $1 \mathrm{~mm}$ ) used as WE in the experiments.

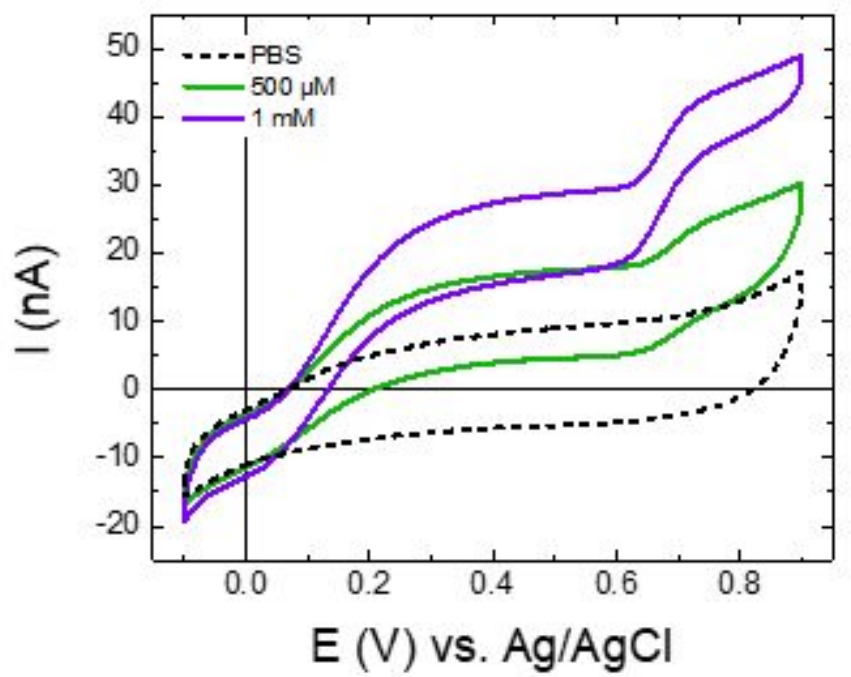

Figure S2. Cyclic voltammograms recorded with a platinized Pt UME (WE1) between $-0.1 \mathrm{~V}$ and $+0.9 \mathrm{~V}$ vs $\mathrm{Ag} / \mathrm{AgCl}$ in solutions of combined $\mathrm{H}_{2} \mathrm{O}_{2}+\mathrm{NO}_{2}{ }^{-}$prepared at the same concentrations in PBS (10 mM, pH 7.4).

\section{REFERENCES}

(1) Girard, F.; Peret, M.; Dumont, N.; Badets, V.; Blanc, S.; Gazeli, K.; Noël, C.; Belmonte, T.; Marlin, L.; Cambus, J.-P.; et al. Correlations between Gaseous and Liquid Phase Chemistries Induced by Cold Atmospheric Plasmas in a Physiological Buffer. Phys. Chem. Chem. Phys. 2018, 20 (14), 9198-9210. 
(2) Ben-Amor, S.; Devin, A.; Rigoulet, M.; Sojic, N.; Arbault, S. Oxygen Plasma Treatment of Platinized Ultramicroelectrodes Increases Sensitivity for Hydrogen Peroxide Detection on Mitochondria. Electroanalysis 2013, 25 (3), 656-663.

(3) Ben-Amor, S. Capteurs Électrochimiques Pour La Caractérisation Du Métabolisme Oxydatif Mitochondrial. Thesis, Université Bordeaux 1, France, 2013. 